\title{
THE IMPACT OF PATIENT'S SOCIO-DEMOGRAPHIC CHARACTERICTICS, COMORBIDITIES AND ATTITUDES ON FLU VACCINATION UPTAKE IN FAMILY PRACTICE SETTINGS VPLIV BOLNIKOVIH PSIHOSOCIALNIH ZNAČILNOSTI, KOMORBIDNOSTI IN STALIŠČ NA ODLOČITEV O CEPLJENJU PROTI GRIPI V AMBULANTAH DRUŽINSKE MEDICINE
}

\author{
Andrej KRAVOS ${ }^{1 *}$, Lucija KRAČUN² ${ }^{2}$ Klara KRAVOS ${ }^{3}$, Rade ILJAŽ2
}

\author{
${ }^{1}$ University of Maribor, Faculty of Medicine, Department of Family Medicine, Taborska ul. 8, 2000 Maribor, Slovenia \\ ${ }^{2}$ University of Ljubljana, Faculty of Medicine, Department of Family Medicine, \\ Poljanski nasip 58, 1000 Ljubljana, Slovenia \\ 3University of Ljubljana, Faculty of Pharmacy, Aškerčeva c. 7, 1000 Ljubljana, Slovenia
}

\section{ABSTRACT \\ Keywords: \\ vaccination, influenza, family practice, attitudes, chronic diseases}

\section{IZVLEČEK}

Ključne besede: cepljenje, gripa, družinska medicina, stališča, kronične bolezni
Objectives. In Slovenia, the role of family physicians in primary care and preventive procedures is very important. Influenza vaccination rates in Slovenia are low. The reasons for low vaccination rates in Slovenia were not clear. We suppose that patient's beliefs and attitudes are important factors. We assessed patients' opinions regarding the acceptance of flu vaccination by their family physicians and their beliefs and attitudes about flu and vaccination. The aim was to check out factors that influence the decision to take the vaccine in family physician offices.

Methods. This was a cross-sectional, multicenter, observational study in the Styria region in Slovenia. We included patients from seven family physicians during regular office visits. They filled in a questionnaire about their general demographic data and attitudes regarding influenza and vaccination. The main outcome was the decision to be vaccinated.

Results. The logistic regression model identified five predictors for influenza vaccination, namely: heart disease, previous vaccination, an agreement with the beliefs 'the vaccination is an efficient measure to prevent influenza', 'after the vaccination there are usually no important side effects' and 'the vaccination is also recommended for a healthy adult person'. The belief that vaccinations harm the immune system is negatively associated with vaccination.

Conclusions. Patients' beliefs are an important factor to decide for vaccination or not. Family physician teams should discuss with patients their beliefs and concerns about vaccination.

Uvod. V Sloveniji ima zdravnik družinske medicine pomembno vlogo pri izvajanju preventive. Delež cepljenih proti gripi je v Sloveniji nizek. Razlogi za to niso povsem jasni. Preučevali smo mnenje bolnikov glede cepljenja proti gripi pri njihovem družinskem zdravniku ter njihova stališča in prepričanja o gripi in cepljenju. Cilj naloge je bil odkriti dejavnike, ki vplivajo na odločitev o cepljenju vambulanti družinske medicine.

Metode. Raziskava je bila presečna multicentrična opazovalna. Vključili smo bolnike iz 7 ambulant družinske medicine na Štajerskem v Sloveniji. Vzorec je zajemal bolnike, ki so prišli v ambulanto. Izpolnili so vprašalnik z demografskimi podatki ter stališči o gripi in cepljenju. Glavni opazovani dogodek je bil odločitev za cepljenje.

Rezultati. V logističnem regresijskem modelu so bili najpomembnejši napovedni dejavniki odločitve za cepljenje srčna bolezen, cepljenje $v$ preteklosti, strinjanje, da je cepljenje najbolj učinkovit ukrep proti gripi, strinjanje, da cepljenje običajno nima pomembnih stranskih učinkov, in strinjanje, da je cepljenje priporočljivo tudi za odraslo zdravo osebo. Prepričanje, da cepljenje škodi imunskemu sistemu, je negativni napovedni dejavnik odločitve za cepljenje.

Zaključki. Stališča bolnikov so pomemben dejavnik pri odločitvi za cepljenje. V ambulantah družinske medicine bi se morali z bolniki več pogovarjati o njihovih stališčih in pomislekih o cepljenju.

*Corresponding author: Tel: +386 414088 90; E-mail: kravos.andrej@gmail.com 


\section{INTRODUCTION}

Influenza is still an important acute infectious disease. It increases morbidity and mortality during winter every year, especially during pandemic influenza. Adults older than 75 years are at the highest risk for mortality. The mortality risk is higher when circulatory and respiratory diseases are present, and also underlying cancer, diabetes, renal disease and Alzheimer disease have a contribution (1). Influenza vaccination has been shown to be costeffective in reducing morbidity and mortality in the older adult population and in decreasing morbidity, lost work days and the use of health care resources (2). The studies of working age groups reported reductions of 34\%-44\% in physician visits, $25 \%$ in antibiotic use for influenzaassociated illnesses, and $32-45 \%$ in lost workdays for those vaccinated $(2,3)$. Estimated costs among healthy persons aged 18-64 years were calculated between $\$ 60$ and $\$ 4000$ per illness (4).

There are huge differences in seasonal flu vaccination rates between different countries and regions, and there are also differences every year (5-8). The decision to be vaccinated against seasonal influenza depends on different factors. A higher age, chronic health conditions and previous hospitalizations are important predictors of flu vaccination $(5,9)$. In addition, socio-demographic characteristics, cultural differences, economic status and education level are important in the decisionmaking process $(10,11)$. Patients' beliefs regarding influenza infection, a perceived influenza risk, vaccine effectiveness, and likelihood of vaccine side effects, as well as a confidence in a good health status and distrust of modern medicine are important predictors regardless of age, job or socioeconomic status (9). Influenza vaccine uptake in the previous years was one of most important predictors (10). In addition, being married, drinking alcohol, smoking and engaging in regular exercise are all factors associated with flu vaccination uptake (11). Also, media coverage of vaccine-related issues, social group norms about health behavior and peer group influences may play a role $(12,13)$. Many studies found an important role of physicians. Physicians' recommendations are usually important facilitators for vaccine uptake. On the other hand, low vaccination rates can also be explained by physicians' failure to strongly recommend influenza vaccination to their elderly and high risk patients (14).

In Slovenia, the National Institute of Public Health every year publishes a vaccination program and practical recommendations, including seasonal flu vaccination $(15,16)$. According to this program, the vaccination against seasonal influenza is recommended for children, for elderly people aged 65 years or more, for pregnant women and for patients with chronic health conditions. Flu vaccination is also recommended for people who are at a high risk of influenza because of their job (e.g. health care workers, veterinaries, workers in chicken farms...) and for students who work in health institutions during flu season. Nevertheless, the adherence to vaccination varies widely.

In Slovenia, people have an opportunity to be vaccinated in primary health centers by their family physicians, or in regional departments of the National Institute of Public Health. The service of vaccination and flu vaccine is not covered by national health insurance. Only vaccines for patients in risk groups are paid by national health insurance. The cost of flu vaccination, however, is very low, especially for elderly people and patients with chronic illnesses. Some companies also decide to offer free flu vaccination to their workers by a vaccination team that comes to them. Despite that, flu vaccination rate in Slovenia is low. The overall vaccination rate against seasonal influenza was $7.3 \%$ in 2008 . Last year, the overall vaccination rate was only $4.4 \%$ and $16.8 \%$ for people aged 65 or more (17). According to legislation, in Slovenia, the advertisement of the names of vaccines is not allowed, but we can promote protection against infections. Media can have a strong influence on deciding whether or not to be vaccinated. A negative media effect was spread during 2009 influenza pandemic caused by the influenza A (H1N1) 2009 virus (18).

In Slovenia, the role of family physicians in primary care and preventive procedures is very important. The factors influencing patients' decision on taking flu vaccines by their family physicians in Slovenia have not been analyzed yet. This study was designed to find out patients' opinions and attitudes about flu and vaccination, to find out which sources of information are important for patients, and to check if patients feel it is important to take flu vaccinations by their own family physicians. The second goal was to discover possible associations between a decision to take or not to take seasonal flu vaccine with patients' characteristics, and to determine predictors on taking flu vaccinations by their family physicians.

\section{PATIENTS AND METHODS}

\subsection{Study Design}

This was a cross-sectional, multicenter, observational study in Styria region in Slovenia. We included patients who came during our regular family practice visits because of different health problems or the request for flu vaccination. The inclusion criterion was the age of 18 years or more. Patients with acute illnesses were not included in the study. Seven family practice teams from three different primary health centers in Styria region in Slovenia were asked to participate in the study. The patients were asked if they wanted to be vaccinated 
against seasonal influenza. Then, the office nurse or family physician asked them to fulfill a questionnaire about their general data and attitudes regarding influenza and vaccination. The patients were asked to fulfill the data about chronic health conditions, about the source of information about flu and vaccination, and about confidence to take the vaccine by their family physician. Each patient was informed about the survey and had an opportunity to ask more questions. Then he/she gave an informed consent to participate. Patients fulfilled questionnaires after the visit or at home and put them into the box. Each family practice team delivered the same number of questionnaires both for patients that accepted the vaccine and for those that refused it. The questionnaires for both groups of patients were labeled according to the acceptance or refusal of vaccination. We planned to deliver 400 questionnaires to patients from October to November 2009. The questionnaires were delivered during consecutive days to the first five eligible patients to take a flu vaccination until all questionnaires were used.

\subsection{The Questionnaire}

The questionnaire had three parts. In the first part, there were questions about the age, gender, marital and employment status, home location (rural, urban), level of education, socioeconomic status and chronic health conditions (pulmonary and heart disease, diabetes mellitus, rheumatologic and kidney disease, immune system disorders and cancer).

The second part of the questionnaire checked their beliefs and knowledge about influenza and vaccination, their perception of possible side effects, safety and efficacy of influenza vaccination, benefits of vaccination for healthy adults, elderly people or those with chronic health conditions, for workers under risk for virus contact, for companies, about their previous influenza vaccination and possible side effects, and about their trust in pharmaceutical companies producing vaccines.
In last part of the questionnaire, patients reported if anybody recommended influenza vaccination to them, and chose their most important source of information about influenza and vaccination. Patients who accepted vaccination also answered the question as to why they had decided to take the vaccine by their family physicians. Those who had refused vaccination specified reasons for refusal.

\subsection{Statistics}

Continuous data was presented as mean and standard deviation (SD), and compared using the t-test. Categorical data was presented as percentages and frequencies, and differences between proportions were compared using the chi-square test. We calculated Cronbach's alpha coefficient for the second part of the questionnaire as a measure of internal consistency.

We assessed the differences between two groups (vaccinated, not vaccinated) in terms of demographic and socioeconomic data, chronic health conditions and beliefs. For all tests, $\mathrm{p}<0.5$ (2-sided) was considered significant. Logistic regression was performed to find out the most important predictors for the acceptance of influenza vaccination. All analyses were performed using a commercially available software program (SPSS-15.0 statistical software; SPSS Inc, Chicago).

\section{RESULTS}

All family practice teams delivered 400 questionnaires, 200 for each group. The delivery and collection of questionnaires was done in October and November 2009. Out of 400 delivered questionnaires, 300 patients returned them; the response rate was $75 \%$. One questionnaire was not filled in correctly. Therefore, we analyzed 299 questionnaires, 151 from vaccinated patients and 148 from not-vaccinated patients. Table 1 presents age, gender, economic, marital and other socio-demographic characteristics and differences between vaccinated and not-vaccinated patients regarding these characteristics. 
Table 1. The differences between vaccinated and not-vaccinated patients regarding age, gender, economic, marital and other socio-demographic characteristics.

\begin{tabular}{|c|c|c|c|c|}
\hline Diagnosis & $\begin{array}{l}\text { Vaccinated } \\
\mathrm{N}=151(\%)\end{array}$ & $\begin{array}{c}\text { Not-vaccinated } \\
\mathrm{N}=148(\%)\end{array}$ & $\begin{array}{c}\text { All } \\
\mathrm{N}=299\end{array}$ & $\mathrm{p}$ \\
\hline Gender & & & & 0.331 \\
\hline Male & $55(47 \%)$ & $62(53 \%)$ & 117 & \\
\hline Female & $95(52.8 \%)$ & $85(47.2 \%)$ & 180 & \\
\hline Marital status & & & & 0.068 \\
\hline Married & $104(53.6 \%)$ & $90(46.4 \%)$ & 194 & \\
\hline Single & $41(42.3 \%)$ & $56(57.7 \%)$ & 97 & \\
\hline Employment status & & & & 0.011 \\
\hline Employed & $63(41 \%)$ & 91 (59 \%) & 154 & \\
\hline Jobless & 7 (43.7 \%) & $9(56.3 \%)$ & 16 & \\
\hline Self-employed & $6(66.7 \%)$ & $3(33.3 \%)$ & 9 & \\
\hline Retired & $67(62.6 \%)$ & $40(37.4 \%)$ & 107 & \\
\hline Pupil, student & $4(50 \%)$ & $4(50 \%)$ & 8 & \\
\hline Residence location & & & & 0.002 \\
\hline Rural & $95(45 \%)$ & $116(55 \%)$ & 21 & \\
\hline Urban & $54(65.1 \%)$ & $29(34.9 \%)$ & 83 & \\
\hline Educational status & & & & 0.288 \\
\hline Primary school & $30(61.2 \%)$ & $19(38.8 \%)$ & 49 & \\
\hline Secondary school & 83 (51.2 \%) & $79(48.8 \%)$ & 162 & \\
\hline Pre-tertiary education & $12(40 \%)$ & $18(60 \%)$ & 30 & \\
\hline Tertiary education & $23(43.4 \%)$ & $30(56.6 \%)$ & 53 & \\
\hline Socioeconomic status & & & & 0.616 \\
\hline Very bad & $2(33.3 \%)$ & $4(66.7 \%)$ & 6 & \\
\hline Poor & $10(66.7 \%)$ & $5(33.3 \%)$ & 15 & \\
\hline Medium & 76 (48.1\%) & $82(51.9 \%)$ & 158 & \\
\hline Good & $51(51 \%)$ & 49 (49\%) & 100 & \\
\hline Excellent & $9(52.9 \%)$ & $8(47.1 \%)$ & 17 & \\
\hline Age (years: mean + SD) & $54.1 \pm 18.1$ & $46.9 \pm 16.7$ & $50.5 \pm 17.8$ & $<0.001$ \\
\hline
\end{tabular}

SD = standard deviation

It is evident that elderly, self employed and retired people decided to uptake flu vaccine more often (Table 1). Also, patients living in urban areas were more inclined to vaccination. The differences in demographic data, educational status and socioeconomic status regarding the decision to be vaccinated have not reached a statistical importance.

Table 2. The differences between vaccinated and not-vaccinated patients regarding chronic health conditions.

\begin{tabular}{|c|c|c|c|c|}
\hline Chronic health condition & $\begin{array}{c}\text { Vaccinated } \\
\mathrm{N}=151(\%)\end{array}$ & $\begin{array}{c}\text { Not-vaccinated } \\
\mathrm{N}=148(\%)\end{array}$ & $\begin{array}{c}\text { All } \\
\mathrm{N}=299\end{array}$ & $\mathrm{p}$ \\
\hline Pulmonary disease & $20(69 \%)$ & $9(31 \%)$ & 29 & 0.024 \\
\hline Heart disease & $43(71.7 \%)$ & $17(28.3 \%)$ & 60 & $<0.001$ \\
\hline Diabetes mellitus & $22(58.6 \%)$ & $6(21.4 \%)$ & 28 & 0.001 \\
\hline Kidney disease & $3(37.5 \%)$ & $5(62.5 \%)$ & 8 & 0.512 \\
\hline Rheumatologic disease & $23(71.9 \%)$ & $9(28.1 \%)$ & 32 & 0.008 \\
\hline Immunodeficiency & $7(63.6 \%)$ & $4(36.3 \%)$ & 11 & 0.307 \\
\hline Cancer & $11(52.4 \%)$ & $10(47.6 \%)$ & 21 & 0.715 \\
\hline
\end{tabular}


We found some chronic health conditions (heart disease, pulmonary disease, rheumatologic disease and diabetes) to be important reasons for patients to be vaccinated (Table 2). Pertaining to patients with kidney disease, immunodeficiency or cancer, there was not much difference between the vaccinated and non-vaccinated groups.

Table 3. Differences between vaccinated and not-vaccinated patients regarding different beliefs, attitudes and previous vaccinations or side effects.

\begin{tabular}{|c|c|c|c|c|}
\hline The agreement with beliefs and attitudes & $\begin{array}{l}\text { Vaccinated } \\
\mathrm{N}=151(\%)\end{array}$ & $\begin{array}{l}\text { Not-vaccinated } \\
\mathrm{N}=148(\%)\end{array}$ & $\begin{array}{c}\text { All } \\
N=299\end{array}$ & p \\
\hline I have enough information about influenza & 89 (53.3\%) & $78(46.7 \%)$ & 167 & 0.020 \\
\hline $\begin{array}{l}\text { I have enough information about vaccine } \\
\text { safety }\end{array}$ & $84(62.7 \%)$ & $50(37.3 \%)$ & 134 & $<0.001$ \\
\hline $\begin{array}{l}\text { I have enough information about vaccine } \\
\text { efficiency }\end{array}$ & $83(66.9 \%)$ & $41(33.1 \%)$ & 124 & $<0.001$ \\
\hline $\begin{array}{l}\text { I have enough information about possible } \\
\text { side-effects }\end{array}$ & $79(67.5 \%)$ & $38(32.5 \%)$ & 117 & $<0.001$ \\
\hline $\begin{array}{l}\text { Vaccination is an efficient measure to prevent } \\
\text { influenza }\end{array}$ & $96(75 \%)$ & $32(25 \%)$ & 128 & $<0.001$ \\
\hline Vaccination is safe & $100(74.1 \%)$ & $35(25.9 \%)$ & 135 & $<0.001$ \\
\hline $\begin{array}{l}\text { After vaccination there are usually NO } \\
\text { important side-effects }\end{array}$ & 70 (76.1\%) & $22(23.9 \%)$ & 92 & $<0.001$ \\
\hline Vaccination can cause many severe diseases & $6(17.6 \%)$ & $28(82.4 \%)$ & 34 & $<0.001$ \\
\hline Vaccination harms the immune system & $5(13.9 \%)$ & $31(86.1 \%)$ & 36 & $<0.001$ \\
\hline $\begin{array}{l}\text { Vaccination is promoted predominantly } \\
\text { because of manufacturers' profit }\end{array}$ & $8(19.5 \%)$ & $33(80.5 \%)$ & 41 & $<0.001$ \\
\hline $\begin{array}{l}\text { Vaccination is also recommended for a healthy } \\
\text { adult person }\end{array}$ & $118(73.3 \%)$ & 43 (26.7 \%) & 161 & $<0.001$ \\
\hline $\begin{array}{l}\text { Vaccination is reasonable for chronically ill } \\
\text { and elderly people }\end{array}$ & 123 (62.4 \%) & 74 (37.6 \%) & 197 & $<0.001$ \\
\hline $\begin{array}{l}\text { Vaccination is reasonable for persons in higher } \\
\text { risk because of more contacts with other } \\
\text { people }\end{array}$ & 119 (60.1\%) & 77 (39.3 \%) & 196 & $<0.001$ \\
\hline $\begin{array}{l}\text { Vaccination is good for companies because it } \\
\text { reduces sick-leave absence }\end{array}$ & 99 (78 \%) & $58(22 \%)$ & 157 & $<0.001$ \\
\hline $\begin{array}{l}\text { I have been vaccinated before against } \\
\text { influenza }\end{array}$ & $110(76.4 \%)$ & $31(23.1 \%)$ & 141 & $<0.001$ \\
\hline $\begin{array}{l}\text { I have already had side effects after } \\
\text { vaccination }\end{array}$ & 25 (52.1\%) & $23(47.9 \%)$ & 48 & 0.797 \\
\hline
\end{tabular}

Vaccinated patients had more information about influenza as well as efficacy and safety of vaccination (Table 3). Also, other beliefs and attitudes regarding efficacy, safety, side effects and recommendation for vaccination differed between the groups. Vaccinated and not-vaccinated patients had side effects after previous vaccinations.
We tested the questions regarding beliefs, attitudes and previous vaccinations or side effects for internal consistency. Cronbach's alpha coefficient was 0.66. 
Table 4. The logistic regression model which predicts vaccination. $\mathrm{N}=299$.

\begin{tabular}{|c|c|c|c|c|}
\hline Predictors & Chi-square & Impact factor & $\begin{array}{c}95 \% \\
\text { Confidence interval }\end{array}$ & $\mathrm{p}$ \\
\hline Heart disease & 11.4 & 13.52 & $2.98-61.25$ & 0.001 \\
\hline $\begin{array}{l}\text { Belief: Vaccination is an efficient measure to } \\
\text { prevent influenza. }\end{array}$ & 11.0 & 4.27 & $1.81-10.07$ & 0.001 \\
\hline $\begin{array}{l}\text { Belief: After vaccination, there are usually NO } \\
\text { important side-effects. }\end{array}$ & 6.0 & 3.19 & $1.26-8.09$ & 0.014 \\
\hline $\begin{array}{l}\text { Belief: Vaccination does harm to the immune } \\
\text { system. }\end{array}$ & 7.0 & 0.13 & $0.03-0.60$ & 0.008 \\
\hline $\begin{array}{l}\text { Belief: Vaccination is also recommended for a } \\
\text { healthy adult person. }\end{array}$ & 7.2 & 3.43 & $1.39-8.43$ & 0.007 \\
\hline $\begin{array}{l}\text { I have been vaccinated before against } \\
\text { influenza. }\end{array}$ & 20.9 & 6.54 & $2.92-14.62$ & $<0.001$ \\
\hline
\end{tabular}

Dependent variable: $1=$ vaccinated patients, $0=$ not-vaccinated patients.

Logistic regression model identified the most important predictors for influenza vaccination uptake (Table 4), namely: heart disease, previous vaccination and an agreement with the belief that vaccination is an efficient measure to prevent influenza. The statistical model reached sensitivity of $87.0 \%$ and specificity of $78.4 \%$.

Table 5. The differences between groups in terms of the persons who encouraged flu vaccination.

\begin{tabular}{lccc}
\hline Predictors & $\begin{array}{c}\text { Vaccinated } \\
\mathrm{n}=146(\%)\end{array}$ & $\begin{array}{c}\text { Not-vaccinated } \\
\mathrm{n}=129(\%)\end{array}$ & $\begin{array}{c}\text { All } \\
\mathrm{n}=275\end{array}$ \\
\hline Family physician & $70(50 \%)$ & $70(50 \%)$ & 140 \\
Other physician & $7(50 \%)$ & $7(50 \%)$ & 14 \\
$\begin{array}{l}\text { Other health } \\
\text { care workers }\end{array}$ & $3(42.9 \%)$ & $4(57.1 \%)$ & 7 \\
$\begin{array}{l}\text { Family, friends, } \\
\text { neighbours }\end{array}$ & $5(26.3 \%)$ & $14(73.7 \%)$ & 19 \\
$\begin{array}{l}\text { Patient's own } \\
\text { decision }\end{array}$ & $57(81.4 \%)$ & $13(18.6 \%)$ & 70 \\
Company & $3(33.3 \%)$ & $6(66.7 \%)$ & 9 \\
Other & $1(6.3 \%)$ & $15(93.7 \%)$ & 16 \\
\hline
\end{tabular}

Chi-square: $p<0.001$

Patient's own decision was important in decision making (Table 5). Family physician most commonly promoted flu vaccination, but there was no difference between groups. $47.9 \%$ of vaccinated patients and $54.3 \%$ of notvaccinated patients reported that their family physician encouraged them to take the flu vaccine. A lot of notvaccinated patients did not take the flu vaccine in spite of the encouragements from family physicians. Patients' family and friends were less important. Also, other doctors and health care workers did not significantly influence patients' decisions. Multiple answers were possible.

Most patients obtained information about vaccination from their family physicians (45\%), media (29\%) and family, friends or neighbors (29\%). Other health workers were a source of information for $13 \%$ of patients. Most vaccinated patients got the information from their family physicians (56\%), whereas most not-vaccinated patiens got it from media (44\%). The difference was statistically significant (Chi-square: $\mathrm{p}<0.001$ ).

About $75 \%$ of vaccinated patients answered that it is important for them to be vaccinated by their family physician. The main reasons included: the best knowledge of patient's medical problems and trust between a patient and family doctor. Safety and the quality of procedures were not among very important reasons. Only vaccinated patients were asked to answer this question.

Not-vaccinated patients were asked about reasons for the refusal of vaccination. The most common reasons were good health condition (31 \%) and fear of side-effects (26\%). Many patients generally did not support vaccination (17\%). Some believed that vaccination is not effective $(8 \%)$ and a few that the cost of vaccination is too high. Some patients wrote also other reasons.

\section{DISCUSSION}

Our study found out that heart disease and certain patients' beliefs are the most important predictors to take flu vaccinations by their family physicians. Family physicians recommended vaccination to $50.9 \%$ of their patients. 
Vaccinated patients trusted their family physicians and perceived their recommendations as important sources of information regarding flu and vaccination. The media is the most important source of information for notvaccinated patients.

In our study, several factors were associated with influenza vaccination. We found that elderly and retired people decided to uptake influenza vaccination more often than younger or employed people. This is a well known fact also from other studies $(5,8,18,19)$. This effect is not specific only to influenza vaccination. Elderly people are also more inclined to pneumococcal vaccination $(20,21)$. People with chronic health conditions decided to take the vaccine more often. Chronic heart disease was the most important predictor for vaccination. In addition, patients with chronic pulmonary disease, diabetes mellitus and rheumatologic disease were more inclined to vaccination. Almost the same conclusions were drawn in the study including Native American elderly people (22). We can find such an effect also in other studies. Chronic health conditions, the number of medications or previous hospitalizations are usually important predictors for the acceptance vaccination $(5,10,19,22-24)$.

Beliefs and attitudes regarding influenza and flu vaccination were important in the decision-making process. Vaccinated patients more frequently answered that they had enough information about influenza compared to not-vaccinated patients. They believed more in the safety and efficacy of the vaccine and less in the potential side-effects of vaccination. They also believed more in the effectiveness of vaccination in elderly people, people with chronic health condition, and even in healthy adults. Furthermore, other studies found some beliefs to be important in the decision-making process (25). Vaccine effectiveness and safety are often found to be important predictors (26). In healthy elderly people, the fear of side-effects of influenza vaccination and a perceived good health seem to be the main factors leading to noncompliance (27). Patients with chronic health conditions are less influenced by the fear of side effects (10). Not-vaccinated patients also showed a higher level of distrust in modern medicine and pharmaceutical companies. This mistrust in medicine and vaccination was partly associated with the coexisting pandemic caused by the influenza A ( $\mathrm{H} 1 \mathrm{~N} 1)$ and numerous media critiques of the recommendations of our health authorities (17). The perceived risk for influenza facilitated the decision of the vaccine uptake $(18,28,29)$.

Our final model identified heart diseases, trust in the efficacy of the vaccine and its safety, and the belief that vaccination is effective also for healthy adults, to be important predictors of vaccination. The most powerful predictor for vaccination was vaccination in previous years. Furthermore, in other studies, past behavior is one of the most powerful predictors of the decision-making process (30).

The recommendation by a family physician was perceived as the major encouraging factor for vaccination, especially for elderly patients $(23,31,32)$. In our study, family physicians recommended flu vaccination to 50.9 $\%$ of patients. Many patients decided to take vaccine on their own. In this study, family physicians' advice has been shown to be less important, but still more important than patients' families or other factors for vaccination. $74.8 \%$ of vaccinated patients answered that it is important to take vaccination by their family physicians, and that the main reason is because their family physicians know all their health conditions. On the other hand, notvaccinated patients reported two main reasons for such a decision: the perception of their good health and fear of side effects.

\subsection{The Limitations of the Study}

Our study has two limitations. The first limitation is the coexistence of influenza A (H1N1) pandemic during the collection of the data. The patients' attitudes were changed during influenza pandemic also in other countries $(33,34)$. The second limitation is that we cannot generalize the data and results to the national level because the sample of patients was limited only to one region in Slovenia. However, a large sample, good response rate and concordance with the results of other studies assure the validity of our results, which should be replicated in further studies.

\section{CONCLUSIONS}

Family physicians in Slovenia often recommend flu vaccination. Patients in general decided for flu vaccination by themselves. Their family physicians proved to be less important in the decision-making process. Vaccinated patients valued family physicians as most important sources of information. On the other hand, media was the most important source of information for not-vaccinated patients. A lot of vaccinated patients said that it was important to be vaccinated by their family physicians and they had confidence in them. Therefore, family physicians should take more time and put in more effort to recommend flu vaccination to their patients and discuss the safety, efficacy and other issues regarding vaccination with them. There are data to promote flu vaccination because of its direct and indirect benefits (35).

\section{ACKNOWLEDGEMENTS}

We would like to thank the nurses of selected GP offices, who took care to collect the questionnaires. 


\section{CONFLICTS OF INTERESTS}

The authors had no conflicts of interest to declare in relation to this article.

\section{ETHICAL APPROVAL}

The study was approved by the Republic of Slovenia National Medical Ethics Committee.

\section{FUNDING}

The study had no financial support.

\section{REFERENCES}

1. Quandelacy TM, Viboue C, Charu V, Lipsitch M, Goldstein E. Age- and sexrelated risk factors for influence-associated mortality in the United States between 1997-2007. Am J Epidemiol 2014; 179: 156-67.

2. Bridges CB, Thompson WW, Meltzer MI, Reeve GR, Talamonti WJ, Cox NJ. et al. Effectiveness and cost-benefit of influenza vaccination of healthy working adults: a randomized controlled trial. JAMA 2000; 284: 1655-63.

3. Nichol KL, Mallon KP, Mendelman PM. Cost benefit of influenza vaccination in healthy, working adults: an economic analysis based on the results of a clinical trial of trivalent live attenuated influenza virus vaccine. Vaccine 2003; 21: 2207-17.

4. Demicheli V, Jefferson T, Rivetti D, Deeks J. Prevention and early treatment of influenza in healthy adults. Vaccine 2000; 18: 957-1030.

5. Shahrabani S, Benzion U. The effects of socioeconomic factors on the decision to be vaccinated: the case of influenza shot vaccination. Isr Med Assoc J 2006; 8: 630-4.

6. Macroepidemiology of Influenza Vaccination (MIV) study group, 2005. The macroepidemiology of influenza vaccination in 56 countries, 1997-2003. Vaccine 2005; 23: 5133-43.

7. Blank PR, Schwenkglenks M, Szucs TD. Vaccination coverage rates in eleven European countries during two consecutive influenza seasons. J Infect. 2009; 58: 446-58.

8. Mereckiene J, Cotter S, Nicoll A, Lopalco P, Noori T, Weber J. et al. Seasonal influenza immunisation in Europe: overview of recommendations and vaccination coverage for three seasons: pre-pandemic (2008/09), pandemic (2009/10) and post-pandemic (2010/11). Euro Surveill 2014; 19 : 20780.

9. Telford R, Rogers A. What influences elderly peoples' decisions about whether to accept the influenza vaccination?: a qualitative study. Health Educ Res 2003; 18: 743-53.

10. Colley E. Influenza vaccination in adults with a long-term condition. Community Pract 2008; 81: 25-28.

11. Andrew MK, McNeil S, Merry H, Rockwood K. Rates of influenza vaccination in older adults and factors associated with vaccine use: a secondary analysis of the Canadian Study of Health and Aging. BMC Public Health 2004; 4: 36-44.

12. Baeyens JP, Lang PO, Michel JP. Willingness to vaccinate and to be vaccinated in adults. Aging Clin Exp Res 2009; 21: 244-9.

13. May T. Public communication, risk perception, and the viability of preventive vaccination against communicable diseases. Bioethics 2005; 19: 407-21.

14. Nichol KL, Zimmerman R. Generalist and subspecialist physicians' knowledge, attitudes, and practices regarding influenza and pneumococcal vaccinations for elderly and other high-risk patients. Arch Intern Med 2001; 161: 2702-8.
15. Program cepljenja in zaščite z zdravili za leto 2014. Available Jan 30, 2015 from: http://img.ivz.si/janez/2541-8637.pdf.

16. Navodila za izvajanje Programa cepljenja in zaščite z zdravili za leto 2014. Available Jan 30, 2015 from: http://img.ivz.si/janez/2541-8149.pdf.

17. Annual report: influence vaccination in Slovenia in season 2012/2013. Ljubljana: IVZ, 2013. Available Sept 3, 2014 from: http://www.ivz.si/ gradiva_cepljenje?pi=5\&_5_Filename=attName.png\&_5_Mediald=6832\&_5_ AutoResize $=$ false\&pl $=106-5.3$.

18. Podlesek A, Roškar S, Komidar L. Some factors affecting the decision on nonmandatory vaccination in an influenza pandemic: comparison of pandemic (H1N1) and seasonal influenza vaccination. Zdrav Var 2011; 50: 227-38.

19. Ward L, Draper J. A review of the factors involved in older people's decision making with regard to influenza vaccination: a literature review. J Clin Nurs 2008; 17: 5-16.

20. Nowalk MP, Zimmerman RK, Tabbarah M, Raymund M, Jewell IK. Determinants of adult vaccination at inner-city health centers: a descriptive study. BMC Fam Pract 2006; 7: 2.

21. Zimmerman RK, Tabbarah M, Nowalk MP, Raymund M, Jewell IK, Block B. et al. Predictors of pneumococcal polysaccharide vaccination among patients at three inner-city neighborhood health centers. Am J Geriatr Pharmacother 2005; 3: 149-59.

22. Buchwald D, Sheffield J, Furman R, Hartman S, Dudden M, Manson S. Influenza and pneumococcal vaccination among native American elders in a primary care practice. Arch Intern Med 2000; 160: 1443-8.

23. Blank PR, Freiburghaus AU, Schwenkglenks MM, Szucs TD, Kunze U. Influenza vaccination coverage rates in Austria in 2006/07 - a representative crosssectional telephone survey. Wien Med Wochenschr 2008; 158:583-8.

24. Sammon CJ, McGrogan A, Snowball J, de Vries CS. Factors associated with uptake of seasonal and pandemic influenza vaccine among clinical risk groups in the UK: an analysis using the General Practice Research Database. Vaccine 2012; 30: 2483-9.

25. Maurer J, Uscher-Pines L, Harris KM. Perceived seriousness of seasonal and A (H1N1) influenzas, attitudes toward vaccination, and vaccine uptake among U.S. adults: does the source of information matter? Prev Med 2010; 51: 1857.

26. Chapman GB, Coups EJ. Predictors of influenza vaccine acceptance among healthy adults. Prev Med 1999; 29: 249-62.

27. Van Essen GA, Kuyvenhoven MM, De Melker RA. Why do healthy elderly people fail to comply with influenza vaccination? Age Ageing 1997; 26: 275-79.

28. Telford R, Rogers A. What influences elderly peoples' decisions about whether to accept the influenza vaccination?: a qualitative study. Health Educ Res 2003; 18: 743-53.

29. Wheelock A, Parand A, Rigole B, Thompson A, Miralco M. et al. Sociopsychological factors driving adult vaccination: a qualitative study. PLoS One 2014; 9: e113503.

30. Gallagher S, Povey R. Determinants of older adults' intentions to vaccinate against influenza: a theoretical application Stephen. J Public Health 2006; 28: $139-44$.

31. Nagata JM, Hernández-Ramos I, Kurup AS, Albrecht D, Vivas-Torrealba C, Franco-Paredes C. Social determinants of health and seasonal influenza vaccination in adults $\geq 65$ years: a systematic review of qualitative and quantitative data. BMC Public Health 2013; 13: 388.

32. Zimmerman RK, Santibanez TA, Janosky JE. What affects influenza vaccination rates among older patients?: an analysis from inner-city, suburban, rural, and Veterans Affairs practices. Am J Med 2003; 114: 31-8.

33. Peretti-Watel P, Verger P, Raude J, Constant A, Gautier A, Jestin C, Beck F. Dramatic change in public attitudes towards vaccination during the 2009 influenza A(H1N1) pandemic in France. Euro Surveill 2013 ;18: 20623.

34. Brandt C, Rabenau HF, Bornmann S, Gottschalk R, Wicker S. The impact of the 2009 influenza A(H1N1) pandemic on attitudes of healthcare workers toward seasonal influenza vaccination 2010/11. Euro Surveill 2011; 16: 19854.

35. Pebody RG, Green HK, Andrews N, Zhao H, Boddington N, Bawa Z. et al. Uptake and impact of a new live attenuated influenza vaccine programme in England: early results of a pilot in primary school-age children, 2013/14 influenza season. Euro Surveill 2014; 19: 20823. 